\title{
Photo Quiz : Deep-seated mycosis
}

症例 65 歳, 男性

輸血後 C 型肝忞で肝硬変一肝細胞癌を発症. 経血管カテーテル動脈塞栓術を数回施行され ていた. 閉塞性黄疸, 胆囊忞で入院となり, 中心静脈カテーテルを挿入され, 経皮経胆管 ドレナージを施行された. 胆汁から Enterococcus, Klebsiella が検出され, clindamy-

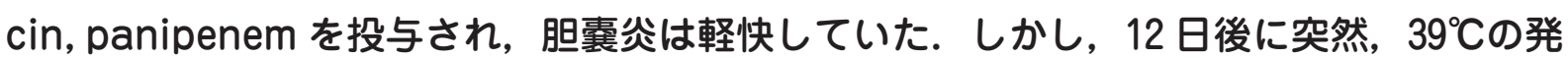
熱, カテーテルを抜去し, 血液培養を施行したところ, 写真のような酵母様真菌が検出さ れた．酵母様真菌の生えた培地シャーレを開けると, シンナー臭がした. fluconazole, amphotericin B を使用するが产の後も発熱は続き, 血液培養から同じ酵母様真菌が検出 され続けた. fluconazole, amphotericin B の MIC はそれぞれ, 4, $0.5 \mu \mathrm{g} / \mathrm{ml}$ であっ た. 产の後, 汎血球減少, 播種性血管内凝固症候群 (DIC) を併発し, 最初の血液培養陽性 時から 2 ヶ月後に死亡した. 最初の血液培養で陽性になったコロニー（サブローブドウ糖 寒天培地, $30^{\circ} \mathrm{C}, 72$ 時間) を示す. クロモアガーカンジダでは紫色のコロニーを呈した.

菌種として何が推定されるか。

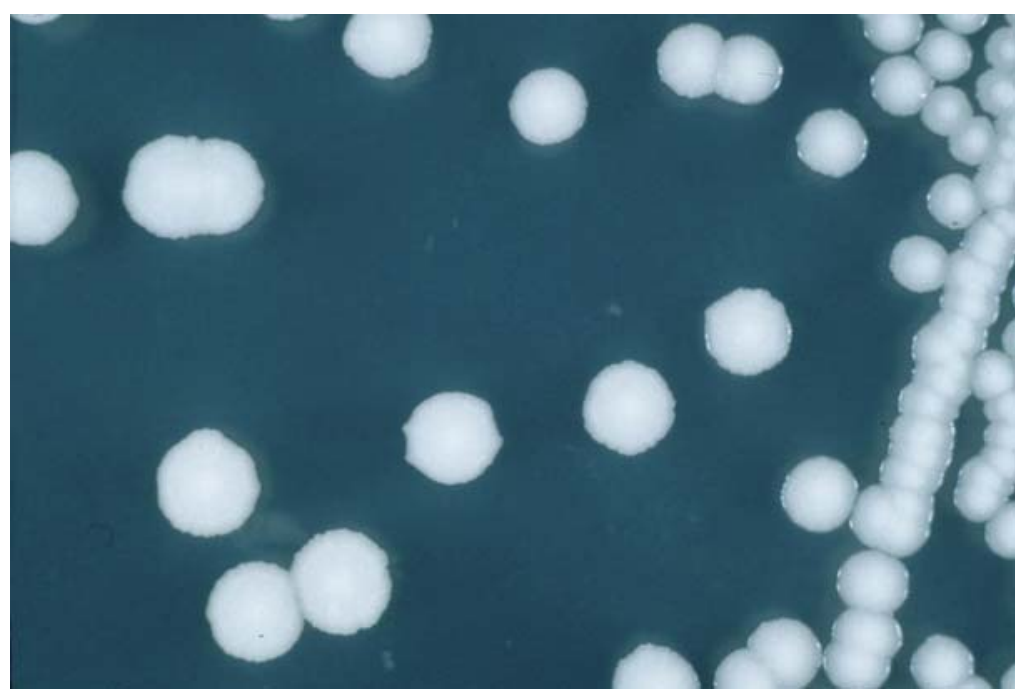

白色，周辺がややラフ型の大きめなコロニーを呈する. 
出題亡解説：菊池＼cjkstart賢（順天堂大学医学部感染制御科学）

\section{解答 Wickerhamomyces anomalus (formerly Pichia anomala)}

菌株はID32C アピで Candida pelliculosa（同定コード4265151011，同定確率 99\%）と同定された.

酶酸塩子囊胞子培地で培養を行ない, Wirtz 染色 (サフラニンとマラカイトグリーンによる染色, 子震胞子が緑色に染 まる）で典型的な “帽子型” 子囊胞子形成が確認された1). 18SrDNA-ITS1-5.8SrDNA-ITS2-26S rDNAD1/D2 region の direct sequence により, 菌種はWickerhamomyces anomalus と同定された.

W. anomalus は環境中に普遍的に存在し, パン種の発酵, ワイン, 清酒醸造時に香気成分を付加する役割をする一方 で，様々な食品や清涼飲料水などの腐敗（シンナ一臭）の原因にもなっている.

Wickerhamomyces 属の菌は各種のエステル産生をすることが知られており, 中でもW. anomalus は酢酸エチル （シンナー臭の元）産生能が高い.

W. anomalus はヒトの皮膚, 口腔咽頭の常在菌ないし通過菌として知られ, 稀にカテーテル血流感染, 感染性心内膜 忿や播種性全身感染を起こす。本症例では感受性があった fluconazole, amphotericin B を使用したにもかかわらず, 治療が奏効しなかった，同様の breakthrough infection はいくつか報告されており，この菌に対する抗真菌薬の効果 は in vitro, in vivo で乘離する可能性も指摘されている2).

W. anomalus は以前は Hansenula anomala, 最近までは Pichia anomala と呼ばれていた真菌であるが, Kurtzman らにより, Pichia 属の再分類が行なわれ, 新設の Wickerhamomyces 属に移されだ3. ちなみにCandida pelliculosa はW. anomalus の anamorph である.

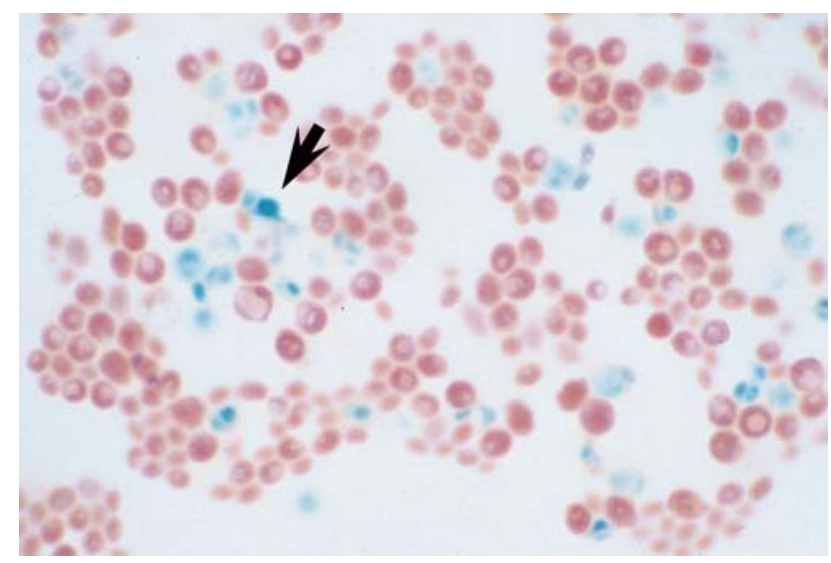

酰酸塩子囊胞子培地 $\left(25^{\circ} \mathrm{C}, 7\right.$ 日培養) 上でのコロニーの Wirtz 染色像

典型的な “hat-shaped” ascospore $(\rightarrow)$ が観察できる.

\section{文献}

1) Larone DH : Medically important fungi, 4th edition, ASM Press, Washington DC, 2002.

2）鶴岡直樹 他：Pichia anomala による内因性感染が疑われた敗血症の 2 例. 日本臨床微生物学雑誌 8 ：68, 1998.

3) Kurtzman CP, et al : Phylogenetic relationships among species of Pichia, Issatchenkia and Williopsis determined from multigene sequence analysis, and the proposal of Barnettozyma gen. nov., Lindnera gen. nov. and Wickerhamomyces gen. nov. FEMS Yeast Res 8 : 939, 2008. 